\title{
NUTRITION AND IMMUNITY IN THE ELDERLY
}

\author{
RANJIT KUMAR CHANDRA
}

Memorial University of Newfoundland and Director of Immunology, Janeway Child Health Centre and Director, World Health Organization Collaborating Centre for Nutritional Immunology, St John's, Newfoundland, Canada

\section{CONTENTS}

INTRODUCTION

THE IMMUNE SYSTEM .

ADAPTIVE IMMUNITY

Cell-mediated immunity.

Antibodies

Complement system

Phagocytes

NUTRITION AND IMMUNITY

DEFICIENCIES OF TRACE ELEMENTS AND VITAMINS

NUTRITION AND IMMUNITY IN OLD AGE

IMMUNE RESPONSES IN OLD AGE.

NUTRITIONAL DEFICIENCIES

EFFECTS OF NUTRITIONAL COUNSELLING AND SUPPORT OF IMMUNE RESPONSES

\section{INTRODUCTION}

Interest in the health of senior citizens has been stimulated by the steady progressive growth of population above the age of 65 years. In addition, it is recognized that the amount of health care expenditure on the elderly is markedly out of proportion to their proportion in the population. This is because older individuals are ill much more often than younger persons and their illness is often longer lasting, even terminal. For these reasons, the state of their health is a matter of great concern not only to the elderly themselves but also to physicians, sociologists and health administrators.

Much of the early work on interactions of nutrition and immunology was done on young children in developing countries but the results of those studies have been shown to be applicable to individuals and populations in industrialized countries and to other agegroups, including the elderly. Indeed there are many similarities between young infants and the elderly. Both have less than optimum immune responses, both are at high risk of developing infection, and in both, dietary factors may be important (Chandra, 1975a, $b$, $1984 b)$.

In the present review, the concept that nutrition is a critical determinant of immunocompetence and risk of illness in old age is reviewed; this will be discussed in three 
sections: a description of the immune system, nutritional regulation of immunity, and the evidence for the role of nutrition in immunocompetence and risk of illness in old age. Some of the material in the present paper is derived from recent review articles on this topic (Chandra 1989a, b, 1991).

\section{THE IMMUNE SYSTEM}

In the last 20 years, there has been a logarithmic increase in our knowledge related to host defences. It has become evident that the immune system is a complex set of interacting cells and their products which have the principal aim of preventing disease such as infection, cancer, autoimmunity, etc. In the present review, a brief description of the immune system is given for a proper understanding of subsequent discussion of nutrition-immunity interactions. We are exposed every day to a battery of micro-organisms in our environment including viruses, bacteria, fungi and occasionally parasites. Pathogens have many different forms and life cycles. Unless checked, these microbial agents can invade mucosal, cutaneous and systemic sites, multiply and cause pathological damage resulting in symptoms and signs. The clinical manifestations of infectious illness can involve all organ systems and may vary from mild to life-threatening. The majority of episodes of exposure to micro-organisms result in no illness or symptoms of short duration with complete recovery. This is the direct result of host defence mechanisms that protect us throughout our lives.

There are two principal divisions of immunity: innate and adaptive. The two interact with each other and provide synergistic protection against infection. The innate or antigennon-specific processes include intact physical barriers of skin and mucous membranes, complement system that includes both classical and alternative pathways of activation, phagocytes, lysozyme, mucus, ciliary movement, etc. The adaptive or antigen-specific immune responses have two tiers: antibodies which are of five different immunoglobulin isotypes (IgG, $\operatorname{IgA}, \operatorname{IgM}, \operatorname{IgD}, \operatorname{IgE}$ ) and many subclasses, and cell-mediated immunity that relies on thymus-dependent $(\mathrm{T})$ lymphocytes. Some of the important elements of host defences are shown in Fig. 1.

\section{ADAPTIVE IMMUNITY}

Although antibodies and cell-mediated immune responses act in concert, each is somewhat more important for different types of micro-organisms. For instance, antibodies produced by $\mathrm{B}$ lymphocytes recognize extracellular antigens, whereas $\mathrm{T}$ lymphocytes recognize intracellular antigens expressed on the surface of body cells. Examples of the two types of micro-organisms include Staphylococcus and respiratory syncytial virus respectively.

\section{Cell-mediated immunity}

The heterogeneity of $\mathrm{T}$ lymphocytes that are responsible for cell-mediated immunity has been demonstrated in the last 10 years. There are two major types of T cell. CD4 + (helper) cells recognize antigens associated with major histocompatibility complex (MHC) class II molecules, whereas CD8 + suppressor cells recognize antigens associated with MHC class I molecules. Not only are there distinct antigens on the surface of these two types of $\mathrm{T}$ lymphocytes, but they subserve distinct functions.

$\mathrm{CD} 4+\mathrm{T}$ cells play an important role in immunoregulation. Antigen from microorganisms is first endocytosed by antigen-presenting cells, such as macrophages, becomes associated with MHC class II molecules, and is expressed at the surface of macrophages and allied cells for recognition by CD4 + helper cells. This leads to $\mathrm{T}$ cell activation and release of several soluble mediators of immune responses, collectively called cytokines. The 


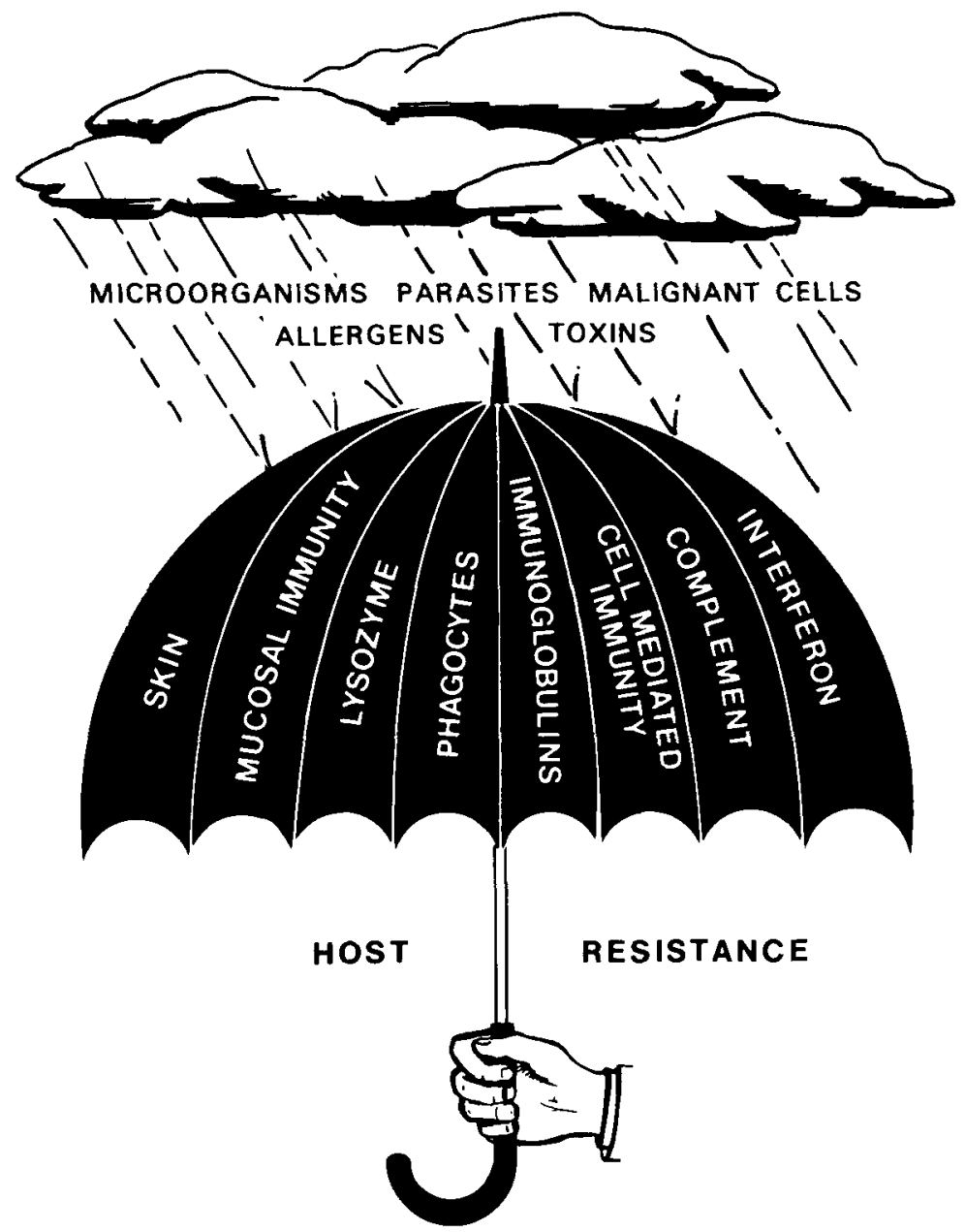

Fig. 1. Host defence mechanisms. Copyright ARTS Biomedical Publishers, 1991.

latter can activate macrophages which will then attempt to destroy intracellular microorganisms. Cytokines also interact with $\mathrm{B}$ cells to activate them to produce antibodies. In selected instances, CD4 + cells and cytokines can also activate other cells.

CD8 + cells provide an inhibitory function, suppressing cell-mediated immune responses. In addition, activated CD8 + cells can kill virus-infected cells. This is achieved by the recognition of viral proteins associated with MHC class I molecules that are expressed on the cell surface, followed by $\mathrm{T}$ cell-mediated killing.

This brief description of cell-mediated immune responses indicates the critical importance of $\mathrm{MHC}$ molecules in antigen recognition by immunocompetent $\mathrm{T}$ cells. Since MHC molecules differ between individuals, this may be one of the reasons for variable susceptibility of individuals to infection.

\section{Antibodies}

There are two main fragments of the immunoglobulin molecule. One part, the Fc or crystalline fragment, can interact with the complement components as well as with various cells of the immune system. The other, Fab or antibody fragment, binds specifically to the 
antigen which stimulated the production of antibody. Antibodies can interact with antigens in solution or with those expressed on the surface of cells. They often mediate protection by acting as cross-links for antigens to Fc receptors on host cells, e.g. neutrophils and macrophages. Antibodies can also sensitize cells for attack by cytotoxic cells that express Fc receptors. Antibodies also play an important role in inflammatory processes.

\section{Complement system}

There are nine components of the complement system; many have subcomponents and inhibitors. Complement is an important mediator of inflammation and can be activated by an antibody via the classical pathway or by certain microbial antigens via the alternative pathway. Thus, it takes part in both innate and adaptive immune responses. The two pathways merge at $\mathrm{C} 3$, which on activation gets cleaved into $\mathrm{C} 3 \mathrm{a}$ and $\mathrm{C} 3 \mathrm{~b}$ fragments. This event leads to activation of the final lytic pathway, via the participation of components $\mathrm{C} 5$, $\mathrm{C} 6, \mathrm{C} 7, \mathrm{C} 8$ and $\mathrm{C} 9$. The generation of active fragments of various complement components is responsible for a variety of functions, including phagocytosis, chemotaxis, cellular activation, stimulation of metabolic pathways of neutrophils and macrophages, anaphylaxis, increased capillary permeability, and damaging the cell surface of microorganisms.

\section{Phagocytes}

Microphages (neutrophils) and macrophages (mononuclear cells) take up microorganisms and destroy them inside phagolysosomes. This microbicidal activity is due to reactive oxygen molecules and their byproducts, which act in concert with halides such as iodide. Enzymes released into phagocytic vacuoles damage microbial surfaces and lead ultimately to their death. As discussed earlier, phagocytes are able to recognize target antigens through antibody binding to Fc receptors on their surface or through complement binding to $\mathrm{C} 3$ receptors. Phagocytes are also antigen-presenting cells and by association of antigen-MHC molecules, help in the recognition of antigen by CD4 + and CD8 + cells. On activation, phagocytes release a variety of cytokines which promote cell activation or may lead to cytotoxic injury to target cells.

\section{NUTRITION AND IMMUNITY}

The interactions of nutrition and immunity have been the focus of much research in the last two decades. A brief description of the effects of nutrition on the immune system is given here. Several monographs and review articles have provided a comprehensive account of the field (Beisel, 1982; Chandra, 1983 b, 1988 b; Keusch et al. 1983; Watson, 1984).

Epidemiological studies have documented the adverse effect of protein energy malnutrition (PEM) on morbidity and mortality. Pathological examination of tissues from children dying of PEM showed the frequent presence of several opportunistic microorganisms including Pneumocystis carinii. Morbidity due to diarrhoeal disease is increased particularly among those children whose weight-for-height is less than $70 \%$ of standard.

Lymphoid tissues show a significant atrophy. For instance, the size of the thymus is small. Histologically, there is a loss of corticomedullary differentiation, there are fewer lymphoid cells, and the Hassal bodies are enlarged, degenerated and, occasionally, calcified. In the spleen, there is a loss of lymphoid cells around small blood vessels. In the lymph node, the thymus-dependent areas show depletion of lymphoid cells.

Delayed cutaneous hypersensitivity responses both to recall and new antigens are markedly depressed. There is a significant positive correlation between the size of skin 
response and visceral protein synthesis as judged by serum albumin concentration. It is not uncommon to have complete anergy to a battery of different antigens. These changes are observed in moderate deficiencies as well. Findings in patients with kwashiorkor were more striking compared with those in marasmus. One plausible reason for reduced cell-mediated immunity in PEM is the reduction in mature fully differentiated $T$ lymphocytes that can be recognized by the classical technique of rosette-formation or by the newer method of fluorescent labelling with monoclonal antibodies. The reduction in serum thymic factor activity observed in PEM may underlie the impaired maturation of $\mathrm{T}$ lymphocytes. There is an increase in the amount of deoxynucleotidyl transferase ( $E C 2.7 .7 .7)$ activity in leukocytes, a feature of immaturity. The recent availability of monoclonal antibodies has provided an excellent tool for the identification and enumeration of subsets of $T$ cells. Cell flow methods showed that the number of helper T4 cells was decreased markedly, often to values less than $50 \%$ of controls. The change in number of suppressor $\mathrm{T}$ cells is less marked. Thus, the helper:suppressor ratio is significantly decreased. Lymphocyte proliferation and synthesis of DNA are reduced, especially when autologous patient plasma is used in cell cultures. This may be the result of inhibitory factors as well as deficiency of essential nutrients lacking in patient's plasma.

Serum immunoglobulin levels are increased, largely a consequence of repeated infections. In addition, reduction in suppressor $T$ cells may be contributory. Serum antibody responses are generally intact in PEM, particularly when antigens in adjuvant are administered or in the case of those materials that do not evoke $T$ cell response. Rarely, the antibody response to organisms such as Salmonella typhi may be decreased. Before impaired antibody response can be attributed to nutritional deficiency, one must carefully rule out infection as a confounding factor. Recently, we have found that antibody affinity is decreased in patients who are malnourished. This may provide an explanation for a higher frequency of antigen-antibody complexes found in such patients. As opposed to serum antibody responses, secretory IgA antibody levels after deliberate immunization with viral vaccines are decreased; there is a selective reduction in secretory IgA levels. This may have several clinical implications, including an increased frequency of septicaemia in undernourished children.

Neutrophil function is also affected in PEM. Complement is an essential opsonin and the levels and activity of most complement components are decreased. The best documented is a reduction in complement $\mathrm{C} 3$, factor $\mathrm{B}$, and total haemolytic activity. Although the ingestion of particles by phagocytes is intact, subsequent metabolic activation and destruction of bacteria is reduced. Finally, recent work in man and animals has demonstrated that the production of interleukin-1 is decreased in PEM.

\section{DEFICIENCIES OF TRACE ELEMENTS AND VITAMINS}

Human malnutrition is usually a complex syndrome of multiple nutrient deficiencies. However, observations in laboratory animals deprived of one dietary element and findings in rare patients with a single nutrient deficiency have confirmed the crucial role of several vitamins and trace elements in immunocompetence. Deficiencies of pyridoxine, folic acid, vitamin $A$, vitamin $C$ and vitamin $E$ result in impaired cell-mediated immunity and reduced antibody responses. Pyridoxine deficiency results in decreased lymphocyte stimulation response to mitogens such as phytohaemagglutinin. A moderate increase in vitamin A intake enhances immune response and affords partial protection against the development of certain tumours in animals.

Zinc deficiency, both acquired and inherited, is associated with lymphoid atrophy, decreased cutaneous delayed hypersensitivity responses and homograft rejection, and lower 
thymic hormone activity. In laboratory animal models these findings can be confirmed and in addition one can demonstrate reduced number of antibody-forming cells in the spleen and impaired T-killer cell activity. Wound healing is impaired. Excess $\mathrm{Zn}$ also depresses neutrophil function and lymphocyte responses. Deficiency of iron is the commonest nutritional problem worldwide, even in industrialized countries. On the one hand, free $\mathrm{Fe}$ is necessary for bacterial growth: removal of Fe with the help of lactoferrin or other chelating agents reduced bacterial multiplication, particularly in the presence of specific antibody. On the other hand, $\mathrm{Fe}$ is needed by neutrophils and lymphocytes for optimal function: bacterial capacity is reduced in Fe deficiency. Also, the lymphocyte proliferation response to mitogens and antigens is impaired: response to tetanus toxoid and herpes simplex antigens was low in Fe-deficiency subjects and $\mathrm{Fe}$ therapy resulted in a significant improvement in their response. There are many molecular explanations for impaired lymphocyte and neutrophil function in Fe deficiency, including the deficiency of myeloperoxidase $(E C 1.11 .1 .7)$ and ribonucleotidyl reductase $(E C 2.8 .8 .7)$. Copperdeficient animals show a reduction in the number of antibody-producing cells compared with healthy and pair-fed controls. Thymic factor activity is reduced. The effect of single nutrient deficiency on serum thymic hormone activity has been evaluated recently. $\mathrm{Zn}$ is critical to the biological activity of thymic inductive factors; as much as $80 \%$ of such activity is lost when $\mathrm{Zn}_{\mathrm{n}}$ is chelated. Pyridoxine also exerts a significant influence on thymic factor activity. On the other hand, the activity of thymulin is not affected significantly by deficiencies of $\mathrm{Cu}$, vitamin $\mathrm{A}$ and selenium.

\section{NUTRITION AND IMMUNITY IN OLD AGE}

Four key questions in the field of nutrition and immunity in old age have been posed (Chandra, 1989 b). First, is immunological decline an inevitable part of ageing? Second, what are the prevalence, pattern and determinants of nutritional deficiencies seen in the elderly? Third, what are the effects of dietary nutritional intervention on immunity of individuals above 65 years of age? Finally, what are the practical applications of the interactions between nutrition and immunity, with particular reference to the risk of illness and response to vaccination in old age.

\section{IMMUNE RESPONSES IN OLD AGE}

The pattern of illness observed in the elderly suggests that immune responses decline in old age. Indeed this has been shown both in man and laboratory animals. Because of the close contact between the immune system and other systems in the body, any changes in immunocompetence may be expected to influence other organ functions as well. As immunological vigour declines, the incidence of infections, cancer, immune complex disease, autoimmune disorders, and amyloidosis increases. Cellular and molecular manipulation to prevent or slow the decline of immune functions may be expected to delay the onset or decrease the severity of pathology associated with ageing.

Age-related changes in immune responses have been the focus of much recent work (Roberts-Thomson et al. 1974; Weksler \& Hutteroth, 1974; Makinodan \& Adler, 1975; Goidl et al. 1976; Girard et al. 1977; Mascart-Lemone et al. 1982; Hicks et al. 1983; Nagel et al. 1983; Sohnle et al. 1983; Antonaci et al. 1984; Fabris et al. 1984). The topic has been reviewed extensively (Makinodan \& Kay, 1980; Kay, 1983, 1985; Fox, 1984; Chandra, 1985 ) and is summarized here.

The number of pluripotent cells with the ability to colonize peripheral lymphoid sites and to mature into competent cells decreases with age in many, but not all, strains of animals. 
Table 1. Delayed cutaneous hypersensitivity responses

(Values are shown as percentage of positive responders among apparently healthy individuals without evidence of acute or chronic systemic disease)

\begin{tabular}{lcccccc}
\hline $\begin{array}{l}\text { Age-groups } \\
\text { (years) }\end{array}$ & Candida & SK-SD & Trichophyton & Tetanus & PHA & DNCB \\
\hline $21-40$ & 78 & 82 & 62 & 82 & 88 & 100 \\
$41-60$ & 64 & 76 & 60 & 70 & 76 & 92 \\
$61-80$ & 46 & 58 & 40 & 62 & 64 & 74 \\
$81-100$ & 38 & 50 & 42 & 54 & 64 & 68 \\
\hline
\end{tabular}

SK-SD, streptokinase-streptodornase; DNCB, dinitrochlorobenzene; PHA, phytohaemagglutinin.

Table 2. Prognostic significance of lymphocyte count and anergy

(The values are based on a group of 400 apparently healthy individuals who were followed for at least 3 years. None of the subjects had clinical evidence of serious systemic disease at the time of first examination when skin test and blood counts were performed)

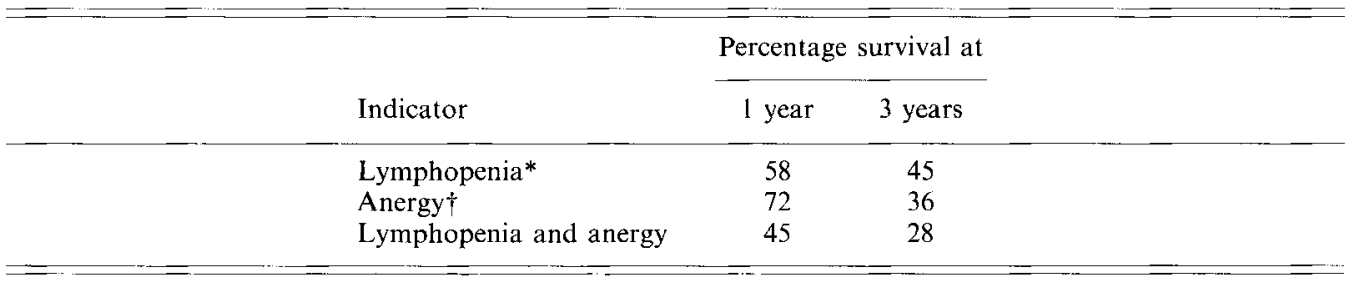

* Count less than 1500 per $\mathrm{mm}^{3}$.

$\dagger$ Anergy as absence of response to four ubiquitous recall-antigens (Candida, streptokinase-streptodornase, tetanus toxoid, Trichophyton).

In serial transplantation experiments, cells obtained from older donors show impaired regenerative ability several passages earlier than cells from younger donors. The ability of stem cells to undergo clonal proliferation decreases with age and the generation of $B$ cells and homing of precursor cells into the thymus is reduced. This restraint on stem cell kinetics and reserves may be critical to an effective response to stress such as infection. Elderly patients with sepsis often fail to mount leucocytosis, although the expected shift to left of immature polymorphonuclear leucocytes does occur. The bone modelling ability of osteoclasts, presumably monocytes derived from haematopoietic stem cells, is compromised in old age and may contribute to age-related osteopenia and aggravate changes resulting from altered mineral intake and metabolism.

The functional attributes of thymus-derived $T$ cells include delayed hypersensitivity reactions, production of various immunomodulating factors, killing of tumour cells, lysis of virus-infected cells, and transplantation rejection. In individuals above the age of 65 years, delayed cutaneous hypersensitivity responses to ubiquitous recall antigens derived from bacterial and fungal products as well as 2,4-dinitrochlorobenzene are reduced in frequency (Table 1) and in size. Lymphopenia and anergy have important prognostic significance in old age (Table 2). The number of circulating $\mathrm{T}$ lymphocytes is normal or slightly decreased. Results of studies enumerating $T$ cell subsets are conflicting; the number of CD4 + cells is decreased, whereas the number of CD8 + cells is variously reported as normal, decreased or increased. Functional alterations associated with these changes in the number of cells include decreased lymphocyte proliferation response to mitogens and antigens, reduced production of macrophage migration inhibition factor and of interleukin- 
2, impaired mixed lymphocyte reaction, and decreased natural killer cell activity. There is a sharp decline in thymulin activity.

There is a reduction in serum IgG concentration and increase in serum IgA level. The proliferative response of $\mathrm{B}$ cells to bacterial lipopolysaccharide is normal or marginally reduced. In old animals, primary antibody response is decreased but antibody titre after booster immunization is comparable in young and old animals. There is a delay in reaching peak response. For many antigens, antibody production by $\mathrm{B}$ cells requires the help of $\mathrm{T}$ cell-generated helper factors. For such antigens, antibody responses are decreased in old age. The affinity of antibody may be reduced. There is no information on secretory IgA antibody responses of old individuals.

Polymorphonuclear leucocytes obtained from the elderly have reduced migration ability, both random and chemotactic. The uptake of micro-organisms is slightly reduced and has been attributed to a more rigid cell membrane. The ability to kill ingested bacteria is largely intact. There is partial limitation to the magnitude of metabolic burst associated with phagocytosis and lysis of Candida is impaired. Much of the information on macrophage function in old age is derived from animal work. In old mice, the number of peritoneal macrophages and their handling of bacteria is intact. The activity of lysosomal enzymes in splenic macrophages increases with age. The production of interleukin-1 is unaffected by aging. The antigen-processing ability of macrophages may be compromised in old age.

The importance in human studies of looking prospectively at the performance of individuals rather than collecting only cross-sectional group data must be emphasized. In addition, the cohort effect must be recognized. Those who are currently 65 years old are different from those who crossed that age some time back, and are now 75 or 85 years old. They are different in financial status, education, quality of medical care, physical activity, and presumably, in nutrition. For these same reasons, older persons are less homogeneous as a group than are young persons. The accumulation of biological and historical experiences over a person's life time makes him or her increasingly different from the next person. In particular, the loss of a spouse has an important and significant effect on immunocompetence of the elderly. For all these reasons, the present group of 80-year-olds is more diverse than the present 50 -year-olds who are in turn more heterogeneous than the group of 20-year-olds today. This is reflected in immunological responses as well, as shown in Fig. 1. Although the mean lymphocyte responses decline with ageing, the range is considerably wider in the elderly and a significant proportion continue to mount immune responses as vigorous as those seen in younger persons. One would like to entertain the possibility that those at the upper end of the immune response capacity are nutritionally better off than those at the lower end of the scale.

\section{NUTRITIONAL DEFICIENCIES}

The different epidemiological approaches to the study of nutritional deficiencies in old age have been reviewed by Burr (1985) and are summarized here. Clinical examination can reveal signs of severe nutritional deficiencies but these are rare in industrialized countries and are largely non-specific. For example, pedal oedema may be due to nutritional hypoalbuminaemia or the result of several systemic diseases such as cardiac and renal pathology. Anthropometric evaluation provides an objective method of diagnosing PEM and the recent publication of normative standards for the elderly (Chumlea et al. 1985) is helpful in this regard. Surveys of dietary intakes, using questionnaires about food frequency, food amounts or weighed inventories, provide data that can be assessed in relation to recommended allowances of various nutrients (Durnin, 1985). However, it must be emphasized that current recommendations vary from country to country, and are largely 
Table 3. Deficient nutrient intake and prevalence of nutritional deficiencies in noninstitutionalized apparently healthy elderly subjects in Newfoundland

\begin{tabular}{|c|c|c|}
\hline Variable & $\begin{array}{l}\text { Percentage of } \\
\text { individuals with } \\
\text { deficient intake } \uparrow\end{array}$ & $\begin{array}{c}\text { Percentage of } \\
\text { individuals with } \\
\text { low blood levels }\end{array}$ \\
\hline Energy & 18 & NA \\
\hline Protein & 12 & 40 \\
\hline Haemoglobin & $\mathrm{NA}$ & 5.5 \\
\hline Albumin & $\mathrm{NA}$ & $7 \cdot 5$ \\
\hline lron* & 22 & 10.5 \\
\hline Zinc & 24 & 14.0 \\
\hline Selenium & 3 & 0 \\
\hline Copper & 4 & 0 \\
\hline Vitamin A & 7 & $5 \cdot 5$ \\
\hline Thiamin & 6 & $2 \cdot 0$ \\
\hline Riboflavin & 4 & $3 \cdot 5$ \\
\hline Pyridoxine & 9 & 60 \\
\hline Vitamin $B_{12}$ & 4 & 30 \\
\hline Folic acid & 8 & $4 \cdot 5$ \\
\hline Vitamin $\mathrm{C}$ & 21 & $16 \cdot 5$ \\
\hline
\end{tabular}

NA, not applicable.

* Blood iron status was measured as serum ferritin concentration.

$\dagger$ The thresholds for defining reduced dietary intake and low blood levels are described in Chandra $(1989 \mathrm{c})$.

derived by extrapolation from information in young adults. There is urgent need for developing age-related recommendations for optimum nutrient intake. Mortality statistics have limited value since deaths are rarely attributed to nutritional deficiencies, which may nevertheless have contributed to the fatal illness. Biochemical assessment is a useful objective method of estimating the prevalence of nutrient deficiencies in the elderly.

Several recent studies have attempted assessment of dietary intake, nutritional status and body composition of the elderly (Schorah et al. 1979; Exton-Smith \& Caird, 1980; Garry et al. 1982; Puri \& Chandra, 1985; Steen et al. 1985; Bogden et al. 1987; Sahyoun et al. 1988; Swanson et al. 1988; Chandra, 1989a). It is important in these studies to diagnose and note the presence of underlying systemic pathology. Also, the institutionalized elderly differ in several aspects from the independent ones, and observations on these two groups should be analysed separately. Based on anthropometric and biochemical evaluation, the prevalence of nutritional deficiencies in apparently healthy independently living elderly in Newfoundland is shown in Table 3.

Certain old individuals are particularly at high risk of malnutrition: the physically isolated, those living alone specially those who have been recently bereaved, the socially isolated, those with sensory or mental impairment, those with a chronic systemic disease, the very poor and the very old. A reduction in total energy intake results in inadequate consumption of certain essential nutrients, for example $\mathrm{Zn}$. This is further compounded by a lack of variety and characteristic self-selection of food items (Krondl \& Coleman, 1985), the presence of malabsorption in some elderly individuals (Fox, 1984) and drug-nutrient interactions (Roe, 1985). Furthermore, it may be postulated that the ability of cells to retain nutrients may be compromised with ageing.

The simultaneous assessment of nutritional status and immune responses and subsequent correlation analysis suggested that impaired immunity in the elderly may be due in part to associated nutritional deficiencies (Chavance et al. 1985; Romagnoli-Juillard et al. 1985; Sakamoto et al. 1985; Bogden et al. 1987). 
Table 4. Effect of correction of nutritional deficiencies on immune responses in the elderly (After an initial period of 6 months, nutritional counselling and appropriate supplements were provided for 6 months to correct diagnosed nutritional deficiencies. Follow-up observations were made 6 months after stopping supplements. Values are means with their standard errors)

\begin{tabular}{|c|c|c|c|c|c|c|c|}
\hline \multirow[b]{2}{*}{ Period } & \multicolumn{2}{|c|}{$\begin{array}{l}\text { Lymphocyte } \\
\text { stimulation } \\
\text { index }\end{array}$} & \multicolumn{2}{|c|}{$\begin{array}{l}\text { NK cell } \\
\text { activity } \\
\left(\%{ }^{51} \mathrm{Cr}\right. \\
\text { release })\end{array}$} & \multirow{2}{*}{$\begin{array}{c}\text { Delayed } \\
\text { hypersensitivity } \\
\text { (no. positive/ } \\
\text { no. tested) }\end{array}$} & \multicolumn{2}{|c|}{$\begin{array}{c}\text { IL-2 } \\
(\mathrm{U} / \mathrm{ml})\end{array}$} \\
\hline & Mean & $\mathrm{SE}$ & Mean & $\mathrm{SE}$ & & Mean & $\mathrm{SE}$ \\
\hline Pre-intervention & 28 & 7 & 21 & 3 & $18 / 60$ & $2 \cdot 4$ & 0.8 \\
\hline Supplementation & 68 & 11 & 42 & 6 & $37 / 59$ & $7 \cdot 1$ & $1 \cdot 2$ \\
\hline Follow up & 51 & 9 & 36 & 5 & $28 / 53$ & $5 \cdot 9$ & 0.7 \\
\hline
\end{tabular}

Pre-intervention values were significantly different from those at the end of supplementation and follow-up periods for all four tests $P=<0.01,<0.001,<0.05$ and $<0.001$ between preintervention and supplemented groups in the four columns respectively (Student's $t$-test and $\chi^{2}$ test). NK, natural killer; IL-2, interleukin-2.

\section{EFFECTS OF NUTRITIONAL COUNSELLING AND SUPPORT ON IMMUNE RESPONSES}

The adverse effects of nutritional deficiencies on a variety of immune responses in children and young adults are now well recognized (Chandra, 1979, 1983 b; Beisel, 1982; Watson, 1984). This may apply to the elderly as well. It is attractive to postulate that nutritional engineering may alter immunocompetence and, thereby, reduce the burden of illness in the elderly (Chandra $1986 a, b, 1987$ ).

Very few studies have attempted correction of nutritional deficiencies in the elderly and examined the effects of such an intervention on immune responses. In an early study, we looked at the nutritional and immunological status of a group of apparently healthy elderly who had no evidence of an underlying systemic disease. Among those with clinical, haematological and biochemical cuidence of nutritional deficiency, there was a significant reduction in delayed cutaneous hypersensitivity reactions, number of $\mathrm{T}$ cells and their response to phytohaemagglutinin (Chandra et al. 1982). Nutritional advice and a supplement to increase energy intake by approximately $2090 \mathrm{~kJ}(500 \mathrm{kcal}) / \mathrm{d}$ and to provide at least the recommended allowances of vitamins and trace elements for a period of 8 weeks resulted in improved skin test responses, an increase in $\mathrm{T}$ lymphocyte number including CD4 + subset, and in lymphocyte proliferation response to phytohaemagglutinin. This improvement in immunological responses was associated with evidence of improved nutritional status, as assessed by levels of albumin, prealbumin, transferrin, retinol-binding protein, $\mathrm{Zn}$ and $\mathrm{Fe}$ (Chandra et al. 1982). Prealbumin levels were reported to correlate with impaired immune responses (Moulias et al. 1985). In a recent study, we found improved natural killer cell activity, mitogen-induced lymphocyte stimulation response, enhanced delayed cutaneous hypersensitivity, higher antibody-forming cell response in the reverse haemolytic plaque assay and increased interleukin-2 production in elderly subjects who were given appropriate nutritional advice and supplements to correct identified nutritional deficiencies (Table 4).

The well-documented effects of various nutrients in maintenance of optimum immunity (Beisel, 1982; Chandra \& Dayton, 1982; Chowdhury \& Chandra, 1987) have led to limited studies of supplementation with a single nutrient or a group of nutrients. The administration of moderate amounts of $\mathrm{Zn}$ to subjects over 70 years of age was associated with improved delayed cutaneous hypersensitivity (Chandra 1984a). In another study, such a supplement 
increased the number of circulating $\mathrm{T}$ cells, delayed cutaneous hypersensitivity and serum IgG antibody response to tetanus toxoid (Duchateau et al. 1981). The addition of $\mathrm{Zn}$ in vitro corrected impaired natural killer cell activity in vitro (Ventura et al. 1986). A vitamin C supplement enhanced lymphocyte proliferative responses in vitro and skin reactivity to tuberculin in vivo (Schorah et al. 1979). However, caution should be exercised against the use of megadoses of any nutrient. Large doses of $\mathrm{Zn}$ impair cell-mediated immune responses and neutrophil function (Chandra 1984a). Similar adverse effects have been shown for large doses of Se and vitamin E (Chandra, unpublished results) and vitamin A (Chandra, 1989c).

\section{CONCLUDING REMARKS}

There are many practical applications of the observations described previously. Response to immunization, such as influenza virus vaccine, is improved if concomitant nutritional support is provided to those elderly who have documented deficiencies at the time of vaccination (Chandra \& Puri, 1985). Second, post-operative complications occur more frequently and are more severe in elderly subjects who are malnourished (Chandra, 1983a). In elderly individuals undergoing elective surgery, it may be advisable to correct nutritional problems before surgical procedures. Third, correction of nutritional deficiencies is likely to result in decreased illness, mainly as a result of fewer episodes of respiratory illness. Moreover, the duration of each episode is shorter. Finally, it is possible that preventative dietary counselling together with the provision of a daily supplement that supplies at least the minimum requirements of essential micronutrients may improve immune responses and reduce the burden of illness in this age-group.

\section{REFERENCES}

Antonaci, S., Jirillo, E., Ventura, M. T., Garofalo, A. R. \& Bonomo, L. (1984). Nonspecific immunity in aging. Deficiency of monocyte and polymorphonuclear cell-mediated functions. Mechanisms of Ageing and Development 24, 367.

Beisel, W. R. (1982). Single nutrients and immunity. American Joumal of Clinical Nutrition 35, 417-468.

Bogden, J. D., Oleske, J. M., Munves, E. M., Lavenhar, M. A., Bruening, K. S., Kemp, F. W., Holding, K. J., Denny, T. N. \& Louria, D. B. (1987). Zinc and immunocompetence in the elderly. Baseline data on zinc nutriture and immunity in unsupplemented subjects. American Journal of Clinical Nutrition 46, 101-109.

Burr, M. L. (1985). The nutritional state of the elderly. Demographic and epidemiologic considerations. In Nutrition, Immunity and Illness in the Elderly, p. 7 [R. K. Chandra, editor]. New York: Pergamon.

Chandra, R. K. (1975a). Fetal malnutrition and postnatal immunocompetence. American Journal of Diseases of Children 129, 450-454.

Chandra, R. K. (1975b). Antibody formation in first and second generation offspring of nutritionally deprived rats. Science 190, $289-290$.

Chandra, R. K. (1979). Serum thymic hormone activity in protein-energy malnutrition. Clinical and Experimental Immunology 38, 228-230.

Chandra, R. K. (1980). Immunology of Nutritional Disorders. Edward Arnold, London.

Chandra, R. K. (1983a). Nutrition, immunity, and infection. Present knowledge and future directions. Lancet $\mathbf{i}$, 688-691.

Chandra, R. K. (1983b). Numerical and functional deficiency in T helper cells in protein-energy malnutrition. Clinical and Experimental Immunology 51, 126-132.

Chandra, R. K. (1984a). Excessive intake of zinc impairs immune responses. Journal of American Medical Association 252, 1443-I446.

Chandra, R. K. (1984b). Nutritional regulation of immune function at the extremes of life: In infants and in the elderly. In Malnutrition, Determinants and Consequences, p. 245. New York: Alan R. Liss.

Chandra, R. K. (editor) (1985). Nutrition-immunity-infection interactions in old age. In Nutrition Immunity and Illness in the Elderly, p. 87. New York: Pergamon.

Chandra, R. K. (1986a). Can dietary factors alter waning immunocompetence in old age? Proceedings of the XII International Congress of Nutrition, p. 726. London: John Libbey.

Chandra, R. K. (1986b). Nutritional engineering. From basic science to clinical practice. Nutrition Research 6 , $1243-1246$. 
Chandra, R. K. (1987). Nutritional engineering. Dietary manipulation of immunocompetence and risk of infection. In The Nature, Cellular and Biochemical Basis and Management of Immunodeficiencies, p. 417. Stuttgart : Schattauer Verlag.

Chandra. R. K. ed. (1988a). Nutrition and Immumology. New York: Alan R. Liss.

Chandra, R. K. (1988 h). Increased bacterial binding to respiratory epithelial cells in vitamin A deficiency. British Medical Journal 297, $834-5$

Chandra, R. K. $(1989 \mathrm{a})$. Nutritional regulation of immunocompetence and risk of disease in old age. In Nutrition of the Elderly, p. 203. Oxford: Oxford University Press.

Chandra, R. K. (1989 b). Nutritional regulation of immunity and risk of illness in old age. Immunology 67, $141-147$.

Chandra, R. K. $(1989 c)$. Large doses of vitamin A impair immune responses. (Unpublished data).

Chandra, R. K. (1991). Basic immunology and its application to nutrition. In Nutrition and Immunology, [G. Blackburn, editor]. New York: Academic press.

Chandra, R. K. \& Dayton, D. H. (1982). Trace element regulation of immunity and infection. Nutrition Research 2, $721-733$.

Chandra, R. K., Joshi, P., Au, B., Woodford, G. \& Chandra, S. (1982). Nutrition and immunocompetence of the elderly. Effect of short-term nutritional supplementation on cell-mediated immunity and lymphocyte subsets. Nutrition Research 2, $223-232$

Chandra, R. K. \& Puri, S. (1985). Nutritional support improves antibody response to influenza virus vaccine in the elderly. British Medical Journal 291, 705-706.

Chavance, M., Brubacher, G., Herberth, B., Vernes, G., Mitstacki, T., Dete, F., Fournier, C. \& Janot, C. (1985). Immunological and nutritional status among the elderly. In Nutrition. Immunity and Illness in the Elderly, p. 137 [R. K. Chandra, editor]. New York: Pergamon.

Chowdhury, B. A. \& Chandra, R. K. (1987). Biological and health implications of toxic heavy metal and essential trace element interactions. Progress in Food and Nutrition Science 11. 57-113

Chumiea, W. C., Roche, A. F., Steinbaugh, M. I.. \& Gopalswamy, N. (1985). Nutritional assessment of the elderly by recombinant anthropometric methods. In Nutrition, Immunity and Illness in the Elderly, p. 53 [R. K. Chandra, editor]. New York: Pergamon.

Duchateau, J., Delepesse, G., Vrijens, R. \& Collet, H. (1981). Beneficial effects of oral zinc supplementation on the immune response of old people. American Journal of Medicine 70, 1001-1004.

Durnin, J, V. G. A. (1985). Energy intake. energy expenditure, and body composition in the elderly. In Nutrition, Immunity and Illness in the Elderly, p. 19 [R. K. Chandra, editor]. New York: Pergamon.

Exton-Smith. A. N. \& Caird, F. I. (Editors) (1980). Metabolic and Nutritional Disorders in the Elderly. Bristol: Wright.

Fabris, N., Mocchegiani, E., Amadio, L., Zannotti, M., Licastro, F. \& Franceschi, C. (1984). Thymic hormone deficiency in normal aging and Down's syndrome. Is there a primary failure of the thymus? Lancet $\mathbf{i}, 983-986$

Fox, R. A. (editor) (1984). In Immunology and Infection in the Elderly, p. 289. Edinburgh: Churchill Livingstone.

Garry, P. J., Goodwin, J. S., Hunt, W. C., Hooper, E. M. \& Leonard, A. G. (1982). Nutritional status in a healthy elderly population. Dietary and supplemental intakes. American Journal of Clinical Nutrition 36, 319-339.

Girard, J. P., Paychere, M., Cuevas, M. \& Fernandes, B. (1977). Cell-medjated immunity in an aging population. Clinical and Experimental Immunology 27,85-9I

Goidl, E. A., Innes, J. B. \& Weksler, M. E. (1976). Immunological studies of aging. II. Loss of IgG and high avidity plaque-forming cells and increased suppressor cell activity in aging mice. Journal of Experimental Medicine 144, 1037-1048.

Hicks, M. J., Jones, J. F., Thies, A. C., Weigle, K. A. \& Minnich, L. L. (1983). Age-related changes in mitogeninduced lymphocyte function from birth to old age. American Joumal of Clinical Pathology 80. 159-163.

Kay, M. M. B. (1983). Immunodeficiency in old age. In Primary and Secondary Immunodeficiency Disorders, p. 165 (R. K. Chandra, editor). Edinburgh: Churchill Livingstone.

Kay. M. M. B. (1985). Immunobiology of aging. In Nutrition, Immunity and Illness in the Elderly, p. 97 [R. K. Chandra, editor]. New York: Pergamon.

Keusch, G. T., Wilson, C. S. \& Waksal, S. D. (1983). Nutrition, host defenses, and the lymphoid system. Advances in Host Defence Mechanisms 2, 275-359.

Krondl, M. \& Coleman, P. (1985). Food selection and dietary intake of elderly persons. In Nutrition, Immunity and Illness in the Elderly, p. 34 [R. K. Chandra, editor]. New York: Pergamon.

Makinodan, T. \& Adler, W. H. (1975). Effects of aging on the differentiation and proliferation potentials of cells of the immune system. Federation Proceedings 34, 153-158.

Makinodan. T. \& Kay, M. M. B. (1980). Age influences on the immune system. Advances in Immunology 29. 287-330.

Mascart-Lemone, F., Delespesse, G., Servais, G. \& Kunstler, M. (1982). Characterization of immunoregulatory T lymphocytes during ageing by monoclonal antibodies. Clinical and Experimental Immunology 48, $148-154$.

Moulias, R. Devillechabrolle. A.. Congy. F., Wang. A., Marescot, M. R. \& Lesourd, B. (1985). Low prealbumin. A correlate of immunodeficiency in elderly patients. In Nutrition. Immunity and Illness in the Elderly, p. 165 [R. K. Chandra, editor]. New York: Pergamon.

Nagel, J. E., Chrest, F. J., Pyle. R. S. \& Adler, W. H. (1983). Monoclonal antibody analysis of T-lymphocyte subsets in young and aged adults. Immunology Communications 12, 223-261. 
Puri, S. \& Chandra, R. K. (1985). Nutritional regulation of host resistance and predictive value of immunologic tests in assessment of outcome. Pediatric Clinics of North America 32, 499-516.

Roberts-Thomson, I. C., Whittingham, S., Youngchaiyud, U. \& McKay, I. R. (1974). Aging, immune response, and mortality. Lancet ii, 368-372.

Roe, D. A. (1985). Pharmacokinetics and drug-nutrient interactions. In Nutrition, Immunity and Illness in the Elderly, p. 253. New York: Pergamon.

Romagnoli-Juillard, A., Rapin, C. H. \& Poirot, P. (1985). Nutrition and immunity in the elderly. In Nutrition, Immunity and Illness in the Elderly, p. 143 [R. K. Chandra, editor]. New York: Pergamon.

Sahyoun, N. R., Otradovec, C. L., Hartz, S. C., Jacob, R. A., Peters, H., Russell, R. M. \& McGandy, R. B. (1988). Dietary intakes and biochemical indicators of nutritional status in an elderly, institutionalized population. American Journal of Clinical Nutrition 47, 524-533.

Sakamoto, M., Ooyamma, T., Tango, T. \& Nishioka, K. (1985). Association of nutritional indices and immunological parameters in elderly patients, including those with cancer. In Nutrition, Immunity and Illness in the Elderly, p. 234 [R. K. Chandra, editor]. New York: Pergamon.

Schorah, C. J., Newill, A., Scott, D. L. \& Morgan, D. B. (1979). Clinical effects of vitamin C in elderly inpatients with low blood vitamin C levels. Lancet $\mathbf{i}, 403-408$.

Sohnle, P. G., Collins-Lech, C. \& Huhta, K. E. (1983). Kinetics of lymphokine production by lymphocytes from elderly humans. Gerontology 29, 169-175.

Steen, B., Lundgren, B. K. \& Isaksson, B. (1985). Body composition at age 70, 75, 79 and 81 years. A longitudinal population study. In Nutrition, Immunity and Illness in the Elderly, p. 49. New York: Pergamon Press.

Swanson, C. A., Mansourian, R., Dirren, H. \& Rapin, C.-H. (1988). Zinc status of healthy elderly adults. Response to supplementation. American Journal of Clinical Nutrition 48, 343-349.

Ventura, M. T., Crollo, R. \& Lasaracina, E. (1986). In vitro zinc correction of natural killer activity in the elderly. Clinical and Experimental Immunology 64, 223-224.

Watson, R. R. (editor) (1984). In Nutrition, Disease Resistance and Immune Functions. New York: Marcel Dekker.

Weksler, M. E. \& Hutteroth, T. H. (1974). Impaired lymphocyte function in aged humans. Journal of Clinical Investigation 53, 99-104. 